\title{
Performance of soybean seed yield components in a non-preferential cropping
}

season

\author{
M. Peter ${ }^{1}$, I.R. Carvalho ${ }^{2}$, L.L. Ferreira ${ }^{3}$, V.J. Szareski ${ }^{1}$, G.H. Demari ${ }^{1}$, \\ M.H. Barbosa ${ }^{1}$, F. Lautenchleger ${ }^{4}$, J.A.G. Da Silva ${ }^{2}$, N.B. Moura ${ }^{2}$, \\ D.A. Magano ${ }^{2}$, V.Q. de Souza ${ }^{5}$ and A.V.S. Inhaquitti ${ }^{6}$ \\ ${ }^{1}$ Universidade Federal de Pelotas, Capão do Leão, RS, Brasil \\ ${ }^{2}$ Universidade Regional do Noroeste do Estado do Rio Grande do Sul, Ijuí, \\ RS, Brasil \\ ${ }^{3}$ Centro Universitário de Mineiros, Mineiros, GO, Brasil \\ ${ }^{4}$ Universidade Estadual do Centro-oeste, Guarapuava, PR, Brasil \\ ${ }^{5}$ Universidade Federal do Pampa, São Gabriel, RS, Brasil \\ ${ }^{6}$ Universidade Federal de Uberlândia, Uberlândia, MG, Brasil \\ Corresponding author: I.R. Carvalho \\ E-mail: carvalho.irc@gmail.com
}

Genet. Mol. Res. 18 (4): gmr18230

Received December 10, 2019

Accepted August 17, 2019

Published October 18, 2019

DOI http://dx.doi.org/10.4238/gmr18230

\begin{abstract}
We evaluated the performance of 25 soybean genotypes sown in the off-season, to identify the morphological attributes and yield determinants for seed yield in this period. The selected genotypes are commonly used among farmers and were purchased from seed traders. Sowing of soybeans during nonpreferential times is common in the northern part of the state of Rio Grande do Sul where it is sown after maize as a late crop. The objective was to evaluate the most suitable genotypes for nonpreferential cultivation. The experiment was conducted in the agricultural crop year of 2017/2018 in Tenente Portela - RS; the experimental design was a randomized block containing 25 soybean genotypes arranged in three replicates. Analysis of variance showed significance at $5 \%$ probability; there was variability for the first pod insertion height, plant height, number of pods on the main stem, number of pods in the branches, number of branches in the main
\end{abstract}


stem, branch length, number of pods containing one seed, number of pods containing two seeds, number of pods containing three seeds, seed mass per fractional plant due to the pod of origin containing one, two and three seeds and seed yield. The genotypes with the highest seed yield in the off-season period in the Northwest of the state of Rio Grande do Sul were BS 2606 IPRO, BMX Magna RR and M 5947 IPRO. The productivity in $\mathrm{kg}$ per hectare was established with taller plants with superiority in the number of pods on the main stem, these pods being formed by two to three viable seeds.

Key words: Glycine max; Seed production; Key traits

\section{INTRODUCTION}

In Brazil, more than 118 million tons of soybeans were produced in the 2017/2018 agricultural crop, which was grown on 35 million hectares. The state of Rio Grande do Sul had the third highest productive performance in Brazil, with 17 million tons of grains and 5.6 million hectares cultivated (Conab, 2018).

In Brazil, there are many soybean genotypes destined for cultivation in favorable regions, making it possible to use this crop from the south to the north of the country, being sown in the preferential (main crop) and non-preferential (second crop) seasons (Meira et al., 2016; Carvalho et al., 2017; Szareski et al., 2018). The yield of soybean seeds is closely related to the phenotypic adaptability of the genotype to the particular environment and the time of sowing. The implementation of the off-season crop area has shown a great influence on productivity, as well as on the attributes of agronomic interest (Meotti et. al., 2012; Pelegrin et al., 2016; Szareski et al., 2016; Ferrari et al., 2018). Several factors can affect yield components, including unfavorable climatic conditions (Cruz, 2010), disease incidence and insect pests, which are potentially disruptive along the soybean cycle.

In Rio Grande do Sul, there is a possibility of soybean cropping in the off-season due to the large cultivation area with maize, being sown between August and September, where the soybean planted in the second fortnight of December to the second half of January is justified, as an alternative source of income and also as a possibility of establishing a system of crop rotation using maize as the first crop and soybean as a second crop. (Camara, 2015; Carvalho et al., 2016; Follmann et al., 2017; Koch et al., 2018).

In Rio Grande do Sul, the sowing period is weighted by climatic risk zonation, with soybeans destined for cultivation from September 21 to December 31, considering the differences between cycles and maturation groups ( $\mathrm{MG}<6.2),(6.2 \leq \mathrm{MG} \leq 7.2)$ and $(>7.2)$ of soybean (BRAZIL, 2018). This classification takes into account the duration of the soybean cycle between emergence and maturation, determined by the characteristics of the environment where it is implanted. Genotypes with early cycle are sown at the beginning of the soybean implantation window, as those with a long cycle should be sown between the middle and the end of the recommended period for soybean sowing (Oliveira and Rosa, 2014). In this context, the objective of this work was to evaluate the performance of 25 soybean genotypes sown in the off-season, to identify the morphological attributes and yield determinants for seed yield in this period. 


\section{MATERIAL AND METHODS}

The experiment was conducted in the agricultural crop of 2017/2018 in Tenente Portela - RS, at latitude coordinates: $27^{\circ} 22^{\prime} 10.20^{\prime \prime} \mathrm{S}$ and longitude: $53^{\circ} 45^{\prime} 23.00^{\prime \prime} \mathrm{W}$, with an altitude of $420 \mathrm{~m}$. The growing environment consists of a dystrophic red Latosol (Oxisol) (Streck et al., 2008). The climate is classified by Köppen as subtropical humid Cfa and features a hot summer and a wet winter.

The experimental design was a randomized block containing 25 soybean genotypes arranged in three replicates. The experimental units contained five meters of length and four rows, with spacing of $0.45 \mathrm{~m}$ between rows. The initial $0.5 \mathrm{~m}$ of each end of the experimental unit were discarded in order to measure the characteristics only in the useful plot, minimizing the experimental errors.

Seeding was done manually in the second half of January 2018, at a density of 250,000 plants for all genotypes tested. Base fertilization was based on the use of $300 \mathrm{~kg} \cdot \mathrm{ha}^{-1}$ of N-P-K in formulation 02-20-20. Phytosanitary management was carried out in a preventive way according to soybean recommendations, in order to minimize the biotic effects in the results of the experiment, the harvest was carried out in the second fortnight of May, 2018.

The soybean genotypes used were: AS 3610 IPRO, NS 5445 IPRO, FPS Solar IPRO, Produza IPRO, TMG 7062 IPRO, BMX Elite IPRO, NS 5959 IPRO, BS2606 IPRO, BMX Magna RR, BMX Garra IPRO, BMX Potencia RR, FPS Atalanta IPRO, DM 5958 IPRO, M 5947 IPRO, TEC 6702 IPRO, M 5730 IPRO, BMX Tornado RR, DM 6159 IPRO, M 6410 IPRO, BMX Ponta IPRO, BMX Vanguarda IPRO, NS 5909 RG, LG 60163 IPRO, NS 6909 IPRO and AS 3570 IPRO.

In order to obtain the attributes of interest, 10 randomly selected plants were evaluated in each experimental unit, the characters measured were: first pod insertion height (FPI, $\mathrm{cm}$ ); plant height (PH, cm); number of pods in the main stem (NPMS, units); number of pods in the branches (NPB, units); number of branches on the main stem (NBMS, units); branch length (BL, cm); number of pods containing one seed (NP1S, unit); number of pods containing two seeds (NP2S, unit); number of pods containing three seeds (NP3S, unit); seed mass per fractional plant due to the pod of origin containing one, two and three seeds (SM1, SM2 and SM3, grams); seed yield (YIELD, kg.ha ${ }^{-1}$ ).

The data were submitted to the diagnosis of normality and homogeneity of the residual variances, after analyzing the variance at $5 \%$ of probability in order to reveal which characters present variability, those that showed significance were submitted to the complementary analyzes by the multiple comparison test of averages by Duncan at $5 \%$ probability. Afterwards, a linear correlation was performed with the purpose of identifying the association tendencies between the characters. The statistical analyzes were performed using Genes software (Cruz, 2013).

\section{RESULTS AND DISCUSSION}

The analysis of variance (Table 1) showed significance at 5\% probability; there was variability for the 25 soybean genotypes evaluated for the first pod insertion height (FPI), plant height $(\mathrm{PH})$, number of pods on the main stem (NPMS), number of pods in the branches (NPB), number of branches in the main stem (NBMS), branch length (BL), 
number of pods containing one seed (NP1S), number of pods containing two seeds (NP2S), number of pods containing three seeds (NP3S), seed mass per fractional plant due to the pod of origin containing one, two and three seeds (SM1, SM2 and SM3) and seed yield (YIELD).

Table 1: Summary of variance analysis for the 25 soybean genotypes grown in 2017/2018.

\begin{tabular}{|c|c|c|c|c|c|c|c|c|c|c|c|c|c|c|}
\hline & & \multicolumn{13}{|c|}{ Mean squares } \\
\hline & D.F. ${ }^{1}$ & $\mathrm{FPI}^{3}$ & PH & NPMS & NPB & NBMS & BL & NP1S & NP2S & NP3S & SM1 & SM2 & SM3 & YIELD \\
\hline Genotypes & 24 & $128.13^{*}$ & $1335.29 *$ & $402.47 *$ & $1878.29 *$ & $30.24 *$ & $1117.27^{*}$ & $131.87^{*}$ & $512.37 *$ & $587.83^{*}$ & $2.39^{*}$ & $33.94 *$ & $49.19^{*}$ & $10778650.70^{*}$ \\
\hline Blocks & 3 & 59.03 & 484.16 & 276.43 & 877.14 & 19.66 & 560.70 & 9.61 & 137.98 & 1267.46 & 0.36 & 3.34 & 178.18 & 16668533.70 \\
\hline Residue & 890 & 20.91 & 54.97 & 40.42 & 208.63 & 2.87 & 85.07 & 13.74 & 66.92 & 86.44 & 0.32 & 6.69 & 13.87 & 2733171.00 \\
\hline C.V. ${ }^{2} \%$ & & 31.55 & 11.51 & 28.05 & 69.97 & 51.12 & 40.47 & 55.15 & 41.85 & 54.36 & 58.06 & 43.72 & 49.29 & 46.14 \\
\hline \multicolumn{15}{|c|}{$\begin{array}{l}\text { * - Significant values at the } 5 \% \text { level of significance. 1- D.F.- Degrees of freedom 2- C.V.- Coefficient of variation. 3- } \\
\text { FPI - first pod insertion height, PH - plant height, NPMS - number of pods on the main stem, NPB - number of pods on } \\
\text { the branches, NBMS - number of branches on the main stem, BL - branch length, NP1S - number of pods containing } \\
\text { one seed, NP2S - number of pods containing two seeds, NP3S - number of pods containing three seeds, SM1, SM2 e } \\
\text { SM3 - seed mass per plant from pods with on, two and three seeds and YIELD - seed yield. }\end{array}$} \\
\hline
\end{tabular}

There was a great variation (Table 2) for the morphological characters measured in the 25 soybean genotypes, where the first pod insertion height (FPI) was higher for genotypes DM 6159 IPRO, NS 5909 RG, Produza IPRO and BMX Garra IPRO respectively, in contrast the genotype NS 5445 IPRO obtained the lowest emphases for this attribute. Research by Sedyiama et al. (2009) indicate that the minimum length between the soil and the first pod should be 10 to $12 \mathrm{~cm}$, this favors the mechanized harvest mainly in environment with a steep slope, the maintenance of this pattern can contribute concomitantly with the soybean yield, due to the maximization of the reproductive nodes in the main stem.

In relation to plant height $(\mathrm{PH})$, the highest values were found in the BMX Garra IPRO, Produza IPRO and BS 2606 IPRO genotypes, which were above $70 \mathrm{~cm}$ (Table 2). The genotypes AS 3570 IPRO, NS 5445 IPRO, BMX Vanguarda RR and M 5730 IPRO expressed smaller statures (Table 2). Research by Sediyama (2015) showed that soybean genotypes with height between 50 and $70 \mathrm{~cm}$ are more favorable to higher seed yields. Smaller magnitudes of this attribute were revealed for the genotype AS 3570 IPRO being this below the $48 \mathrm{~cm}$. Studies have indicated that soybeans when cultivated in the offseason or non-preferential period result in shorter stature, this is directly attributed to sowing time, photoperiod reduction and cycle shortening (Ludwig et al., 2010; Meier et al. 2016; Muraro et al., 2018).

The number of pods in the main stem (NPMS) was higher in the genotype BS 2606 IPRO (29.7), but for the genotypes TMG 7062 IPRO, NS 5909 RG and LG 60163 IPRO the smallest magnitudes were obtained (Table 2). According to Szareski et al. (2015), the number of pods present on the main stem can correspond to up to two thirds of the total of pods in the soybean plant, in this way; these genotypes stand out as the most productive ones.

The number of pods in the branches (NPB) was superior for the genotypes BS 2606 IPRO, LG 60163 IPRO with 35.7 and 35.2 pods respectively. However, the NS 5445 IPRO and BMX Elite IPRO genotypes expressed less evidence for this character (Table 2).

For the number of branches in the main stem (NBMS) the highest magnitude was observed for genotypes LG 60163 IPRO and BMX Elite IPRO with 5 to 6 branches per 
plant. The branches length (BL) was prominent for genotypes LG 60163 IPRO and NS 5445 IPRO.

The number of pods containing only one seed (NP1S) was higher for the BMX Magna RR and BS 2606 IPRO genotypes. The magnitude of pods with two seeds (NP2S) showed the genotypes BS 2606 IPRO and NS 5445 IPRO as superior, for pods with three seeds (NP3S) the LG 60163 IPRO genotype was highlighted, with more than 25 viable pods (Table 2). The number of pods per plant is characterized as one of the determining factors for the potential productivity of soybean, being the seed dynamics per pod controlled by the pronounced effects of the growing environment (Bárbaro et al., 2006; Ferrari et al. 2016; Zimmer et al., 2016).

The seed mass per plant from pods containing one seed (SM1) revealed superiority for BMX Magna RR, whereas seed mass from pods containing two seeds (SM2) was pronounceable for BS 2606 IPRO, and for seed mass attributed to pods with three seeds (SM3) showed superiority for the M6410 IPRO genotype with an indeterminate growth habit (Table 2).

Table 2. Means for the 25 soybean genotypes for the characters measured in the 2017/2018 agricultural year.

\begin{tabular}{|c|c|c|c|c|c|c|c|c|c|c|c|c|c|c|c|c|c|c|c|c|c|c|c|c|c|c|}
\hline & FPI* & & $\mathrm{PH}$ & & NPMS & & NPB & & NBM & & BL & & NP1S & & NP2S & & NP3S & & SM1 & & SM2 & & SM3 & & YELD & \\
\hline AS 3610 IPRO & 13.68 & $\mathrm{cg}^{(1)}$ & 64.23 & ef & 20.23 & ik & 30.13 & ac & 4.60 & $\mathrm{bc}$ & 30.09 & $\mathrm{ac}$ & 8.53 & $\mathrm{bc}$ & 24.38 & $\mathrm{bc}$ & 19.40 & bg & 1.26 & bd & 6.63 & bf & 7.04 & bf & 3730.7 & cf \\
\hline NS 5445 IPRO & 9.96 & $\mathrm{~h}$ & 53.96 & $\mathrm{j}$ & 24.86 & bg & 9.18 & $\mathrm{j}$ & 2.07 & $\mathrm{jk}$ & 12.03 & $\mathrm{j}$ & 5.39 & eg & 14.39 & $\mathrm{~h}$ & 14.14 & hk & 0.90 & ek & 4.70 & hi & 7.68 & af & 3198.8 & df \\
\hline FPS Solar IPRO & 13.54 & $\mathrm{cg}$ & 64.19 & ef & 22.29 & ej & 16.25 & $\mathrm{fj}$ & 3.38 & $\mathrm{dh}$ & 19.56 & gi & 5.59 & eg & 17.42 & fh & 16.03 & $\mathrm{fj}$ & 0.80 & $\mathrm{gk}$ & 5.14 & $\mathrm{fi}$ & 6.29 & $\mathrm{cf}$ & 2946.4 & ef \\
\hline Produza IPRO & 17.58 & a & 70.97 & $a b$ & 19.00 & $\mathrm{jk}$ & 21.80 & $\mathrm{dg}$ & 4.23 & $\mathrm{~cd}$ & 31.54 & $a b$ & 4.18 & $\mathrm{~g}$ & 15.63 & gh & 20.33 & bf & 0.70 & $\mathrm{jk}$ & 5.58 & ei & 9.04 & $a b$ & 4105.4 & bd \\
\hline TMG 7062 IPRO & 16.05 & $\mathrm{ac}$ & 69.30 & bd & 15.68 & 1 & 20.89 & $\mathrm{dh}$ & 3.61 & $\mathrm{dh}$ & 23.42 & $\mathrm{dg}$ & 5.42 & eg & 18.50 & eh & 16.87 & ej & 0.84 & $\mathrm{fk}$ & 5.87 & ei & 8.95 & $a b$ & 3873.1 & ce \\
\hline BMX Elite IPRO & 11.95 & gh & 59.54 & gi & 25.95 & bd & 9.63 & $\mathrm{Ij}$ & 1.60 & $\mathrm{k}$ & 16.07 & hj & 8.25 & $\mathrm{bc}$ & 16.83 & fh & 9.63 & $\mathrm{k}$ & 1.12 & $\mathrm{cg}$ & 4.66 & i & 6.14 & $\mathrm{df}$ & 2853.9 & $\mathrm{f}$ \\
\hline NS 5959 IPRO & 15.98 & ac & 67.18 & bf & 26.33 & $\mathrm{bc}$ & 10.65 & $\mathrm{Ij}$ & 1.82 & $\mathrm{k}$ & 14.97 & ij & 5.43 & eg & 15.53 & $\mathrm{gh}$ & 14.28 & $\mathrm{gk}$ & 0.79 & $\mathrm{gk}$ & 5.09 & fi & 6.53 & $\mathrm{cf}$ & 2847.3 & $\mathrm{f}$ \\
\hline BS 2606 IPRO & 12.97 & $\mathrm{dg}$ & 70.81 & $\mathrm{ac}$ & 29.74 & $\mathrm{a}$ & 35.72 & $\mathrm{a}$ & 4.19 & $\mathrm{~cd}$ & 31.74 & $a b$ & 11.17 & $\mathrm{a}$ & 30.56 & a & 23.49 & ac & 1.50 & $\mathrm{~b}$ & 8.17 & $\mathrm{a}$ & 8.87 & $a b$ & 5103.8 & $\mathrm{a}$ \\
\hline BMX Magna RR & 13.00 & $\mathrm{dg}$ & 66.77 & $\mathrm{cf}$ & 21.81 & $\mathrm{fj}$ & 33.92 & $a b$ & 5.15 & $\mathrm{ab}$ & 30.37 & ac & 11.76 & a & 25.20 & $\mathrm{~b}$ & 21.35 & ae & 1.81 & a & 7.78 & $\mathrm{ac}$ & 9.13 & $a b$ & 4887.2 & $a b$ \\
\hline BMX Garra IPRO & 16.73 & $a b$ & 73.83 & $\mathrm{a}$ & 26.50 & b & 18.88 & eh & 3.05 & fi & 21.04 & eh & 4.44 & $\mathrm{~g}$ & 21.31 & bf & 18.90 & ch & 0.63 & $\mathrm{k}$ & 6.60 & bf & 8.91 & $a b$ & 4047.6 & bd \\
\hline BMX Potência RR & 14.74 & bf & 69.35 & bd & 21.70 & gj & 21.58 & $\mathrm{dg}$ & 3.68 & dh & 25.55 & ce & 6.98 & be & 16.68 & fh & 19.80 & bf & 0.96 & $\mathrm{dk}$ & 4.79 & gi & 8.01 & af & 3189.3 & df \\
\hline FPS Atalanta IPRO & 15.95 & $\mathrm{ac}$ & 68.95 & bd & 22.29 & ej & 17.29 & ei & 3.16 & ei & 23.50 & $\mathrm{dg}$ & 5.34 & eg & 18.26 & eh & 15.55 & $\mathrm{fj}$ & 0.94 & $\mathrm{dk}$ & 5.47 & ei & 7.41 & af & 3427.5 & cf \\
\hline DM 5958 IPRO & 13.58 & $\mathrm{cg}$ & 64.40 & ef & 25.33 & bf & 16.13 & $\mathrm{fj}$ & 2.78 & hj & 19.56 & gi & 8.35 & $\mathrm{bc}$ & 20.68 & $\mathrm{cf}$ & 12.55 & $\mathrm{ik}$ & 1.21 & be & 6.31 & $\mathrm{cg}$ & 6.02 & ef & 3319.1 & cf \\
\hline M 5947 IPRO & 13.78 & $\mathrm{cg}$ & 67.85 & be & 24.30 & bh & 27.58 & bd & 3.60 & $\mathrm{dh}$ & 25.10 & $\mathrm{df}$ & 7.90 & $\mathrm{bc}$ & 25.38 & b & 18.93 & ch & 1.16 & $\mathrm{cf}$ & 7.85 & $\mathrm{ab}$ & 8.45 & $\mathrm{ac}$ & 4259.5 & ac \\
\hline TEC 6702 IPRO & 15.53 & ad & 63.10 & fg & 19.80 & $\mathrm{ik}$ & 18.75 & eh & 3.18 & ei & 20.79 & eh & 8.80 & b & 17.13 & fh & 12.15 & $\mathrm{jk}$ & 1.36 & $\mathrm{bc}$ & 6.63 & bf & 7.35 & af & 3723.3 & cf \\
\hline M 5730 IPRO & 13.48 & $\mathrm{cg}$ & 56.50 & hj & 21.00 & hj & 23.95 & $\mathrm{cf}$ & 3.28 & $\mathrm{dh}$ & 20.32 & fh & 8.10 & $\mathrm{bc}$ & 22.03 & be & 14.50 & $\mathrm{gk}$ & 1.09 & $\mathrm{ch}$ & 6.77 & ae & 6.19 & cf & 3505.4 & cf \\
\hline BMX Tornado RR & 13.33 & $\mathrm{dg}$ & 59.21 & hi & 22.90 & ci & 23.87 & $\mathrm{cf}$ & 3.87 & $\mathrm{cg}$ & 25.55 & ce & 6.67 & $\mathrm{cf}$ & 18.87 & $\mathrm{dh}$ & 20.60 & bf & 0.98 & $\mathrm{dj}$ & 5.22 & fi & 7.86 & af & 3448.2 & cf \\
\hline DM 6159 IPRO & 17.69 & $\mathrm{a}$ & 69.74 & $\mathrm{bc}$ & 25.39 & be & 13.05 & hj & 2.31 & $\mathrm{ik}$ & 19.08 & gi & 4.82 & fg & 19.36 & $\mathrm{dg}$ & 14.59 & $\mathrm{gk}$ & 0.71 & $\mathrm{jk}$ & 5.93 & ei & 7.60 & af & 3442.6 & cf \\
\hline M 6410 IPRO & 14.73 & bf & 68.05 & be & 24.78 & bg & 29.73 & ac & 3.98 & $\mathrm{cf}$ & 27.70 & bd & 5.70 & $\mathrm{dg}$ & 23.03 & bd & 24.33 & $a b$ & 0.74 & $\mathrm{ik}$ & 6.21 & $\mathrm{dh}$ & 9.47 & $\mathrm{a}$ & 4146.8 & bd \\
\hline BMX Ponta IPRO & 14.95 & be & 65.43 & $\mathrm{df}$ & 22.73 & $\mathrm{di}$ & 24.68 & ce & 3.65 & $\mathrm{dh}$ & 26.61 & $\mathrm{~cd}$ & 5.35 & eg & 19.15 & $\mathrm{dg}$ & 22.88 & $\mathrm{ad}$ & 0.77 & hk & 5.26 & ei & 9.29 & $a b$ & 3679.5 & cf \\
\hline BMX Vanguarda IPRO & 13.98 & $\mathrm{cg}$ & 56.15 & ij & 19.88 & $\mathrm{ik}$ & 16.48 & $\mathrm{fj}$ & 2.75 & hj & 19.02 & gi & 5.33 & eg & 17.20 & fh & 13.78 & hk & 0.64 & $\mathrm{jk}$ & 4.90 & gi & 5.77 & $\mathrm{f}$ & 2898.6 & ef \\
\hline NS 5909 RG & 17.59 & $\mathrm{a}$ & 63.10 & fg & 17.31 & $\mathrm{kl}$ & 19.84 & $\mathrm{dh}$ & 4.03 & $\mathrm{ce}$ & 24.62 & $\mathrm{df}$ & 7.62 & bd & 18.26 & eh & 12.59 & $\mathrm{ik}$ & 1.06 & ci & 5.31 & ei & 5.73 & $\mathrm{f}$ & 2956.8 & ef \\
\hline LG 60163 IPRO & 13.16 & $\mathrm{dg}$ & 64.84 & ef & 17.58 & $\mathrm{kl}$ & 35.22 & $\mathrm{a}$ & 5.58 & $\mathrm{a}$ & 33.52 & A & 5.47 & eg & 20.39 & $\mathrm{cf}$ & 25.67 & a & 0.82 & $\mathrm{fk}$ & 7.55 & ad & 8.32 & $\mathrm{ad}$ & 3663.0 & cf \\
\hline NS 6909 IPRO & 12.30 & fg & 60.04 & gh & 25.60 & be & 16.37 & $\mathrm{fj}$ & 3.00 & gi & 19.62 & gi & 6.77 & bf & 16.83 & fh & 17.77 & $\mathrm{di}$ & 1.23 & be & 6.34 & $\mathrm{cg}$ & 9.06 & ae & 4013.1 & bd \\
\hline AS 3570 IPRO & 12.72 & eg & 48.77 & $\mathrm{k}$ & 22.51 & $\mathrm{dj}$ & 14.72 & gj & 2.05 & $\mathrm{Jk}$ & 14.18 & $\mathrm{j}$ & 5.64 & eg & 16.62 & fh & 14.44 & $\mathrm{gk}$ & 0.92 & ek & 4.95 & gi & 6.58 & $\mathrm{cf}$ & 3010.1 & ef \\
\hline
\end{tabular}

Seed yield (YIELD) was highest for BS 2606 IPRO, BMX Magna RR and M 5947 IPRO genotypes, which obtained averages above 4,000 kg per hectare (Table 2), these three genotypes do not differ statistically among themselves at a $5 \%$ probability level by the Duncan test. Soybean yield is directly linked to acclimatization and adaptation of the genotype to the growing environment that this was inserted, therefore these genotypes listed as more productive tend to be recommended for the production of seeds in non-preferential time in the Northwest of the state of Rio Grande do Sul.

The linear correlations allowed 78 associations, of which 77 were significant at 5\% probability by the $t$ test, when stratifying as to its meaning, 66 were expressed as positive and 11 were contrary trends (Table 3). 
The first pod insertion height (FPI) is interconnected (Table 3) with the plant height, where genotypes with higher heights respond positively to this character, in contrast, reduce the magnitude of pods in the main stem and branches, number of branches on the main stem and branch length, number of pods with one, two and three seeds, as well as the mass of seeds from pods with only one and three seeds, and seed yield per area unit area.

Table 3. Linear correlations among the characters of interest measured in 25 soybean genotypes grown in the 2017/2018 agricultural year.

\begin{tabular}{|c|c|c|c|c|c|c|c|c|c|c|c|c|c|}
\hline & FPI & $\mathrm{PH}$ & NPMS & NPB & NBMS & BL & NP1S & NP2S & NP3S & SM1 & SM2 & SM3 & YIELD \\
\hline $\mathrm{FPI}^{(1)}$ & 1 & $0.23^{*}$ & $-0.25^{*}$ & $-0.26^{*}$ & $-0.17 *$ & $-0.09^{*}$ & $-0.20 *$ & $-0.27^{*}$ & $-0.28^{*}$ & $-0.21^{*}$ & $-0.25^{*}$ & $-0.29 *$ & $-0.32 *$ \\
\hline PH & & 1 & $0.32 *$ & $0.22 *$ & $0.28 *$ & $0.34 *$ & $0.11 *$ & $0.24 *$ & $0.32 *$ & $0.12 *$ & $0.24 *$ & $0.30^{*}$ & $0.31^{*}$ \\
\hline NPMS & & & 1 & $0.20 *$ & $0.04^{\mathrm{ns}}$ & $0.14^{*}$ & $0.30 *$ & $0.43 *$ & $0.44 *$ & $0.25^{*}$ & $0.35 *$ & $0.39 *$ & $0.43^{*}$ \\
\hline NPB & & & & 1 & $0.82 *$ & $0.71^{*}$ & $0.55^{*}$ & $0.79 *$ & $0.77^{*}$ & $0.46^{*}$ & $0.69 *$ & $0.65^{*}$ & $0.81 *$ \\
\hline NBMS & & & & & 1 & $0.67 *$ & $0.40^{*}$ & $0.63^{*}$ & $0.63^{*}$ & $0.35^{*}$ & $0.58^{*}$ & $0.51 *$ & $0.64 *$ \\
\hline BL & & & & & & 1 & $0.40 *$ & $0.58 *$ & $0.58^{*}$ & $0.36^{*}$ & $0.50 *$ & $0.47 *$ & $0.59 *$ \\
\hline NP1S & & & & & & & 1 & $0.51 *$ & $0.26^{*}$ & $0.89^{*}$ & $0.46^{*}$ & $0.22 *$ & $0.45^{*}$ \\
\hline NP2S & & & & & & & & 1 & $0.53^{*}$ & $0.44 *$ & $0.86^{*}$ & $0.41 *$ & $0.70^{*}$ \\
\hline NP3S & & & & & & & & & 1 & $0.22 *$ & $0.46 *$ & $0.90 *$ & $0.81 *$ \\
\hline SM1 & & & & & & & & & & 1 & $0.43 *$ & 0.20 * & $0.45^{*}$ \\
\hline SM2 & & & & & & & & & & & 1 & $0.40 *$ & $0.75^{*}$ \\
\hline SM3 & & & & & & & & & & & & 1 & $0.87^{*}$ \\
\hline YIELD & & & & & & & & & & & & & 1 \\
\hline
\end{tabular}

* - Significant correlations at 5\% level. ${ }^{\text {ns }}$ - Non-significant correlations at 5\% level. ${ }^{-}$FPI - first pod insertion height, PH - plant height, NPMS - number of pods on the main stem, NPB - number of pods on the branches, NBMS - number of branches on the main stem, BL - branch length, NP1S - number of pods containing one seed, NP2S - number of pods containing two seeds, NP3S - number of pods containing three seeds, SM1, SM2 e SM3 - seed mass per plant from pods with one, two and three seeds and YIELD - seed yield.

Higher plants tend to show more pods on the main stem and ramifications, ramifications on the main stem and longer length of these ramifications, while potentiating the magnitude of pods with one, two and three seeds, as well as, the seed mass per plant originated from pods with one, two and three seeds, these attributes together determine the seed yield seeds per plant (Table 3). Studies by Follmann et al. (2017), show that higher plants potentiate grain yield of soybean.

Higher magnitudes in pods on the main stem tend to increase the pods in the branches and their extension, as well as the number and mass of seeds independent of the original pod. The number of pods in the branches is directly related to the magnitude of ramifications per plant and its dimensions, being these responsible for the prominence of a greater number of reproductive units (Table 3 ).

The seed yield per plant was inversely proportional to the first pod insertion height. In contrast, the highest yields were obtained in soybean genotypes that maximize the seed mass per plant and the number of pods containing two and three seeds, plants with branches and taller (Table 3), this will potentiate the probability of formation of reproductive nodes, flower emission and formation of pods, concomitant to this the superiority in number of seeds per plant.

\section{CONCLUSIONS}

The genotypes with the highest seed yield in the off-season in the Northwest of the state of Rio Grande do Sul are BS 2606 IPRO, BMX Magna RR and M 5947 IPRO. 
Productivity was improved through taller plants with superiority in the number of pods on the main stem, these being formed by two to three viable seeds.

\section{CONFLICTS OF INTEREST}

The authors declare no conflict of interest.

\section{REFERENCES}

Bárbaro IM, Centurion MAPC, Di Mauro AO, Unêda-Trevisoli SH, et al. (2006). Path analysis and expected response in indirect selection for grain yield in soybean. Crop Breed. Appl. Biotechnol. 6(2): 151-159. http://dx.doi.org/10.12702/1984-7033.v06n02a06.

Brasil - Ministério da Agricultura, Pecuária e Abastecimento/Secretaria de Política Agrícola - Portaria ${ }^{\circ} 154$, de 25 de julho de 2018. Aprovação do Zoneamento Agrícola de Risco Climático para a cultura de soja no Estado do Rio Grande do Sul, ano-safra 2018/2019. Diário Oficial da União, Brasília, DF, 26 July 2018. Ed. 143, Section 1, Page 5.

Câmara GMS (2015). Preparo do solo e plantio. In: Sediyama, T.; Silva, F. e Borém, A. (Eds.). Soja do plantio à colheita. UFV, Viçosa, p. 66-109.

Carvalho IR, Nardino M and Souza VQ de (2017). Melhoramento e cultivo da soja. Porto Alegre: Cidadela, n. 1, 288 p.

Carvalho IR, Nardino M, Demari G, Bahry CA, et al. (2016). Bisegmented regression, factor analysis and AMMI applied to the analysis of adaptability and stability of soybean. Aust. J. Crop. Sci. 10: 1410-1416. DOI: 10.21475/ajcs.2016.10.10.pne63.

Carvalho IR, Nardino M, Demari G, Szareski VJ, et al. (2017). Relations among phenotypic traits of soybean pods and growth habit. Afr. J. Agric. Res. 12: 450-458.

Companhia Nacional De Abastecimento - Conab. Série histórica: soja. 2018. Available at: <https://portaldeinformacoes.conab.gov.br/index.php/safra-serie-historica-dashboard>. Accessed: October 3, 2018.

Cruz CD. (2013). GENES - a software package for analysis in experimental statistics and quantitative genetics. Acta Sci Agron 35(3): 271-276. http://dx.doi.org/10.4025/actasciagron.v35i3.21251.

Cruz TV, Peixoto CP and Martins MC (2010). Crescimento e produtividade de soja em diferentes épocas de semeadura no oeste da Bahia. Sci. Agrar. Curitiba. 11(1): 33-42.

Ferrari M, Pelegrin AJ, Nardino M, Carvalho IR, et al. (2016). Evaluation of soybeans genotypes in field environments of Rio Grande do Sul state, Brazil. Int. J. Curr. Res. 8: 38383-38392.

Ferrari M, Pelegrin AJ, Carvalho IR, Nardino M, et al. (2018). Path analysis and phenotypic correlation among yield components of soybean using environmental stratification methods. Aust. J. Crop. Sci. 12: 193-202. doi: 10.21475/ajcs.18.12.02.pne488.

Follmann DN, Cargnelutti Filho A, Souza VQ, Nardino M, et al. (2017). Relações lineares entre caracteres de soja safrinha. Rev. Cienc. Agrar. 40: 213-221.

Koch F, Aisenberg GR, Szareski VJ, Demari GH, et al. (2018). Yield and physiological quality of seeds of different bean genotypes produced in the off-season period in subtropical climate. Aust. J. Crop. Sci. 12: 669-675. doi: 10.21475/ajcs.18.12.05.PNE610.

Ludwig MP, Dutra LMC, Lucca Filho AO, Zabot L, et al. (2010). Características morfológicas de cultivares de soja convencionais e Roundup Ready TM em função da época e densidade de semeadura. Cienc. Rural. 40(4): 759-767. http://dx.doi.org/10.1590/S0103-84782010000400003.

Meier C, Meira D, Olivoto T, Follmann DN, et al. (2016). Morphological traits and yield components of second-crop soybeans in Rio Grande do Sul state, Brazil. Aust. J. Basic \& Appl. Sci. 9: 81-88.

Meira D, Carvalho IR, Nardino M, Follmann DN, et al. (2016). Path analysis and dissimilarity in soybean with indeterminate habit. Int. J. Curr. Res. 8: 39568-39573.

Meotti GV, Benin B, Silva RR, Beche E, et al. (2012). Épocas de semeadura e desempenho agronômico de cultivares de soja. Pesq. Agropec. Bras. 47: 14-21.

Muraro DS, Basso CJ, Carvalho IR, Szareski VJ, et al. (2018). Agronomic Components of Brown Linseed as a Function of Spacing. J. Agric. Sci. 10: 527. DOI:10.5539/jas.v10n10p527-533.

Nardino M, Carvalho IR, Demari G, Pelissari G, et al. (2016). Components of variance, linear and canonical correlation soybean cultivars. Aust. J. Basic \& Appl. Sci. 10: 202-208.

Oliveira ACB, Rosa APA. Da (Ed.). Indicações técnicas para a cultura da soja no Rio Grande do Sul e em Santa Catarina, safras 2014/2015 e 2015/2016. EMBRAPA Clima Temperado, Pelotas, In. XL Reunião de Pesquisa de Soja da Região Sul, 2014. EMBRAPA Clima Temperado Documentos 382. Available at :< https://www.infoteca.cnptia.embrapa.br/infoteca/bitstream/doc/1011192/1/IndicacoesTecnicasEmbrapa003.pdf $>$. Accessed: October 29, 2018. 
Pelegrin AJ, Carvalho IR, Nardino M, Ferrari M, et al. (2016). Performance of resistant soybean to asian rust in different environments in RS. Int. J. Curr. Res. 8: 38398-38401.

Sediyama T (Ed.) (2009). Tecnologias de produção e usos da soja. Londrina: Ed. Mecenas, 314p.

Sediyama T, Matsuo E, Oliveira RCT and Glasenapp JS (2015). Características agronômicas de cultivares. In: Sediyama, T. (Ed.). Melhoramento genético da soja. Mecenas, Londrina, p. 73-82.

Streck EV, Kämpf N, Dalmolin RS, Klamt E, et al. (2008). Solos do Rio Grande do Sul. 2.ed. Emater, Porto Alegre, 222 p.

Szareski VJ, Souza VQ, Carvalho IR, Nardino M, et al. (2015). Ambiente de cultivo e seus efeitos aos caracteres morfológicos e bromatológicos da soja. Rev. Bras. Agropec. Sustent. 5: 79/2-88.

Szareski VJ, Carvalho IR, Nardino M, Demari G, et al. (2016). Phenotype stability of soybean genotypes for characters related to the physiological quality of seeds produced under different environmental conditions. Aust. J. Basic \& Appl. Sci. 10: 279-289.

Szareski VJ, Carvalho IR, Nardino M, Pelegrin AJ, et al. (2016). Competition of soybean genotypes cultivated in lowlands of Rio Grande do Sul, Brazil. Int. J. Curr. Res. 8: 39714-39718.

Szareski VJ,. Carvalho IR, Demari GH, Souza VQ, et al. (2018). Multivariate index of soybean seed vigor: a new biometric approach applied to the effects of genotypes and environments. J. Seed Sci. 40: 1-13. http://dx.doi.org/10.1590/2317-1545v40n4198333.

Szareski VJ, Carvalho IR, Demari GH, Pelissari G, et al. (2018). Path analysis applied to agronomic traits of contrasting growth habit soybeans. Aust. J. Crop Sci. 12: 531-538. doi: 10.21475/ajcs.18.12.04.pne608.

Zimmer G, Koch F, Carvalho IR, Szareski VJ, et al. (2016). Seed quality and initial performance os seedlings of soybean produced off-season in Rio Grande do Sul, Brasil. Int. J. Curr. Res. 8: 40325-40329. 